\title{
A Survey of the Effects of Lead on Gunners
}

\author{
Lt Col J R Brown
}

$\mathrm{MB}, \mathrm{MSc}, \mathrm{RAMC}$

\section{Army Occupational Health Research Unit}

SUMMARY: An environmental and biological survey of lead involving 35 soldiers from an artillery training unit was carried out. The soldiers had a minimum of eighteen months service. The eight hour Time Weighted Average (TWA) for lead in air $\left(0.19 \mathrm{mg} / \mathrm{m}^{3}\right)$ exceeded the Standard $\left(0.15 / \mathrm{m}^{3}\right)$ on a maximum of three days per month. However, the weighted average for 40 hours $\left(0.03 \mathrm{mg} / \mathrm{m}^{3}\right)$ was well within the Lead in Air Standard ${ }^{10}$.

No toxic effects on the soldiers were revealed by the biological tests employed.

A comparison of blood lead (BPb) was made with those in a group $(n=292)$ of recruits (Fig. 1) which showed a statistically significant difference $(t(d)$ 328) $=4.28, P<0.001)$.

The survey indicated that the level of lead exposure is not sufficient to require any special monitoring or corrective measures as laid down in the Control of Lead at Work Regulations.

\section{Introduction}

Lead poisoning has been recognised as a clinical entity for centuries. Rising awareness of health problems associated with industry in the latter half of the 19th century lead to it becoming a notifrable disease in Britain in 1889. Since then efforts have been made to control it, particularly in manufacturing industry. Exposure to lead has long been controlled in armament factories where lead and its salts are used in the manufacture of ammunition and explosives. Policies of containment or technological substitution have been widely used this century, often spurred forward by the advent of war. Interestingly, lead azide was substituted for mercury fulminate as a detonant in 1944, in view of the high sickness absence caused by the fulminate in munition workers secondary to contact dermatitis. The fact that most of the workers were women probably hastened the substitution. This change was supported by a technical and medical paper in $1946^{1}$. Lead azide itself has now been replaced by other non metallic compounds. However, much stock ammunition still has it as a constituent and will not be withdrawn from use.

Interest in heavy metal poisoning within the Army Medical Services associated with weapon firing was aroused in the mid-seventies following the publication of Landrigan's ${ }^{2}$ work which was closely followed in Britain by Smith's ${ }^{3}$ important paper on lead absorption in Police Small Arms Instructors. Further reports abound to highlight the problem in indoor ranges ${ }^{4}$. From this arose a survey of airborne lead contamination in Army Indoor Ranges which revealed significant levels of airborne lead in some instances $^{5}$. A continuing programme of environ- mental testing on indoor ranges is now being sế up and will undoubtedly lead to changes in the construction and ventilation of these ranges in the future.

Crown Forces are bound by the Health and Safet at Work Act 1974 in most non-operational spheres

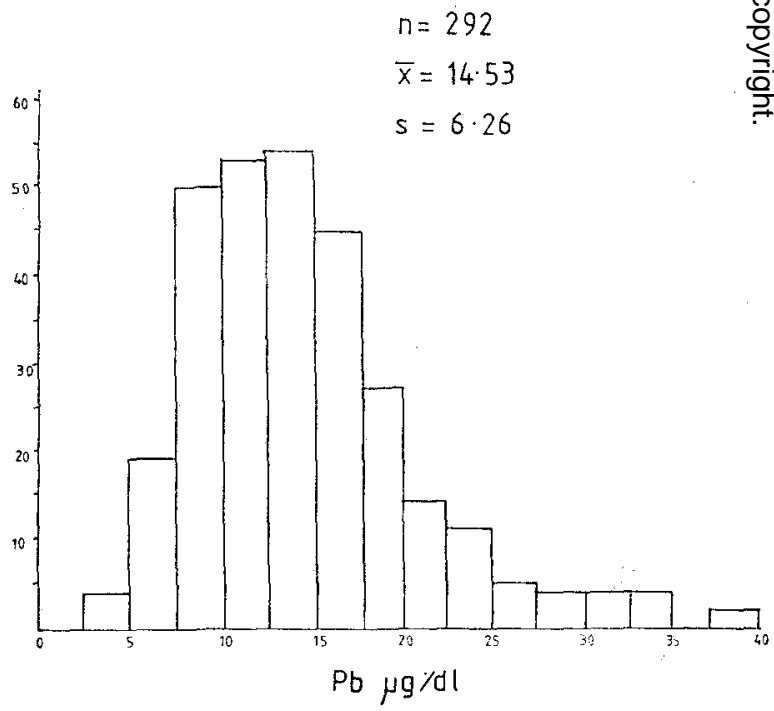

Fig. 1 Blood lead, recruits (Manser $1981^{\circ}$ )

We are open to inspection by inspectors of the Health and Safety Executive but not liable to their various enforcement procedures. However, charges 0 can be taken out against individuals under Criminal 
Law if thought necessary. Happily this has not as yet occurred. The Act commits employers to ensure, as far as is reasonably practicable, the health, safety and welfare at work of all their employees. The Control of Lead Work Regulations $1980^{7}$ stipulates in Regulation 4 that an employer has a responsibility to carry out assessment of work which exposes a person to lead in order to determine the nature and degree of the exposure. In the past, knowledge of the gaseous and particulate by-products of explosives has been based on research and monitoring during the development stage. However, this has always been directed at the two major sources of hazard in the operation, namely carbon monoxide and oxides of nitrogen. There has been little work on the release of lead from adjuncts or components of the detonant, propellant or projectile. I could find no published work on the effect of lead released by artillery fire as distinct from small arms fire. In view of this, it could not be assumed that lead release was likely to bc insignificant and so this survey was carried out.

\section{Aims of the Study}

The primary aims of the study were:

(a) To establish the risk to exposed men from environmental lead released by artillery during firing and to assess any biological effect.

(b) To investigate whether this group of men showed any evidence of increased lead absorption following a minimum period of eighteen months service from that found in a group of recruits.

(c) To formulate recommendations for future control and monitoring as required.

\section{Nature of the Problem}

The Support Regiment at the Royal School of Artillery was selected for the study. It spends much time in practice and demonstration firing and this ensures that the unit, in peace time, uses its guns much more frequently than other regiments. On average, the guns will be fired on four days per week, at least, from 0900 to 1600 hours and every other week, up until midnight. The rate of fire varies greatly from perhaps 20 up to 200 rounds per session. The great bulk of the firing is done using the $105 \mathrm{~mm}$ light gun (Fig. II) and the $105 \mathrm{~mm}$ Abbot self propelled gun. Less than $10 \%$ of the gunners' time is spent firing artillery pieces of different calibres. In addition each soldier carried out training with his personal small calibre weapon which uses jacketed ammunition on about four occasions per year, the lead core has an alloy jacket preventing particulate lead being cvolved). However, lead azide is present in small arms explosive propellant. As he is only likely to fire around 60 rounds on each occasion, on an open air range, this is not likely to give rise to significant levels of airborne lead.

Not all members of the regiment will be directly exposed to breech emissions from guns. A large number of those involved in command, administration and support will have little intimate contact with the guns. The exposed men total about 120 and it is these who were investigated. Soldiers are occupationally exposed to other sources of environmental lead, namely exhaust smoke from petrol engines which often run for hours on end to provide power for radios and field computers as well as a measure of heat for the occupants of the vehicle.

Sixty per cent of the men smoked so are at added risk from direct ingestion of lead due to contamination of the cigarettes from contaminated surfaces.

\section{Nature of the Risk}

The light gun when fired has a $37 \%$ efficience ie $37 \%$ of the propellant gases follow the shell ou@ of the muzzle. A variable proportion remains in the barrel and escapes through the breech whero the empty shell is extracted and a further quantity escapes through the muzzle break of the barrel $\frac{\mathcal{D}}{\mathrm{D}}$ These proportions are not important in a fielo gun as all fumes are dispersed into the air ance carried by the prevailing wind, though they are of importance to a closed gun system, as in the Abboe SP gun. However, the layer (who aims) and the loader (Fig. 2) are directly subjected to the gases as they escape from the breech and, if the wind direction is into the gun, some of the muzzle smoke as well. Other members of the crew will be affected to a lesser degree.

In the Abbot gun the breech is inside the turret and fume concentration can be momentarily high. Extractor fans are activated when the breech is

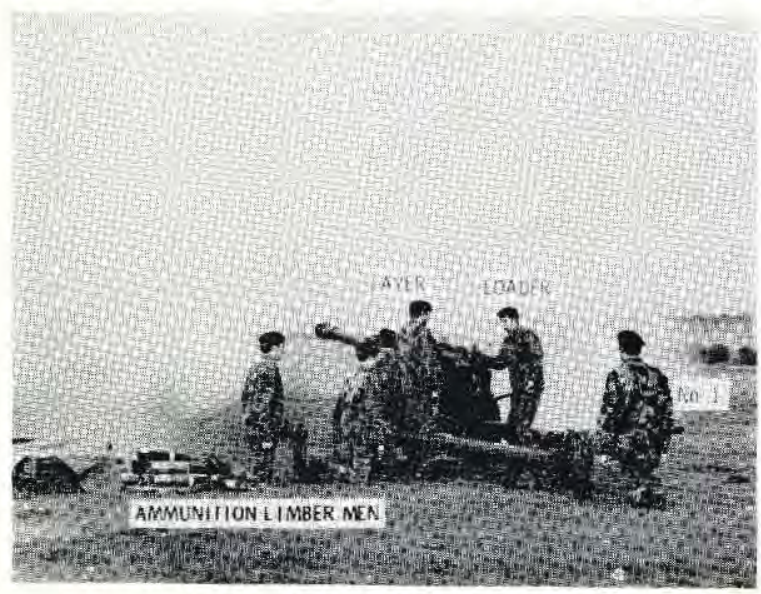

Fig. 2 Light gun crew 
opened, and, although designed to remove oxides of nitrogen and carbon monoxide, they are undoubtedly effective in removing finely particulate lead as well.

A modern shell is comprised of three main components. These are the detonator, the propellant and the projectile (Fig. 3). A range of projectiles are available and these can be driven by propellant (charge) of increasing strength depending on the range, type of projectile and climatic conditions. The charges are contained in a shell case and higher charges are screwed on as an increment. In this way a range of eight charges can be used. The propellant does not contain lead and the projectile is of steel alloy construction apart from a cuprous driving band (Fig. 4). This band locks into the rifling of the gun barrel.

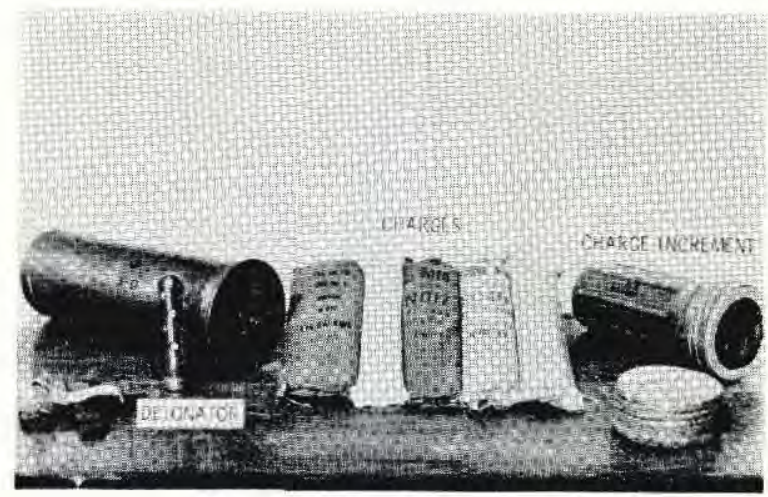

Fig. 3 Propellant assembly

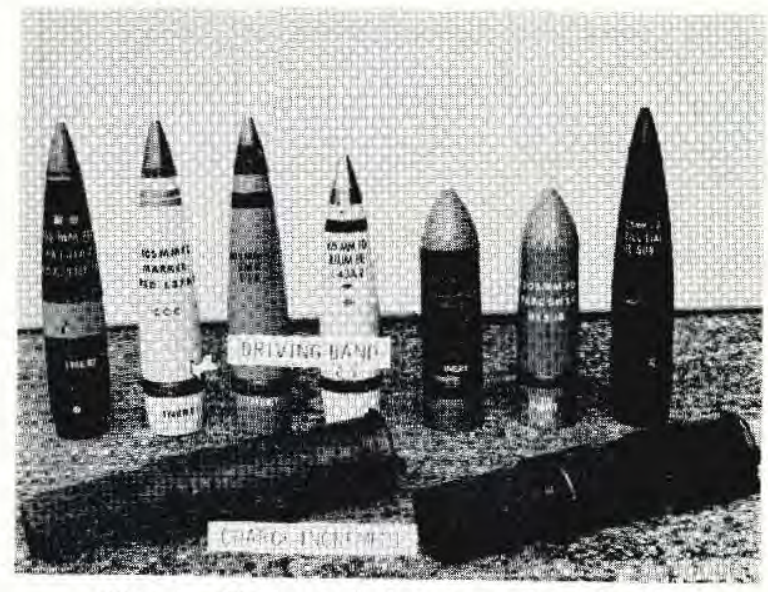

Fig. 4 Varicty of charges and projectiles

A decoppering device is added behind the driving band of the projectile when higher charges are used. This is lead foil and contains $5 \mathrm{~g}$ in the No 4 charge, $16 \mathrm{~g}$ in the No 5 and $17 \mathrm{~g}$ in the super
(No 6) charge. This device helps to prevent copper from fouling and welding to the rifling of the gun barrel at the high breech temperatures achieved with high charges. The lower charges (1-4) do not require a decoppering device and so no lead is evolved which was amply borne out in the survey.

\section{Methods}

The survey consisted of a programme of both environmental and biological testing. Environmental testing was carried out using a Dupont sampler using a cellulose acetate membrane filter with 0.8 $\mathrm{mm}$ pores at a 2 litre per minute flow rate. The samples in each case were drawn from the two most exposed men, namely the loader and layer. Analysis was carried out using an AA-775 atomic absorption spectrophotometer.

Thirty eight volunteers (three being non-exposed medical centre staff) were screened all of whom had more than eighteen months service. A questionnaire was completed and a clinical examination was carried out by the author. Ten $\mathrm{mls}$ of venous blood was obtained and divided into two aliquots, one in lithium heparin for Red Blood Cell Aminolaevulinic acid dehydratase (RBC ALAD) estimation and one in EDTA for blood lead haemoglobin and white cell count (WBC). A fresh sample of urine was also obtained. The RBC ALAD assay was carried out within six hours using the method of Tomokunis which has the advantage that it measures the amount of 5-ALA consumed rather

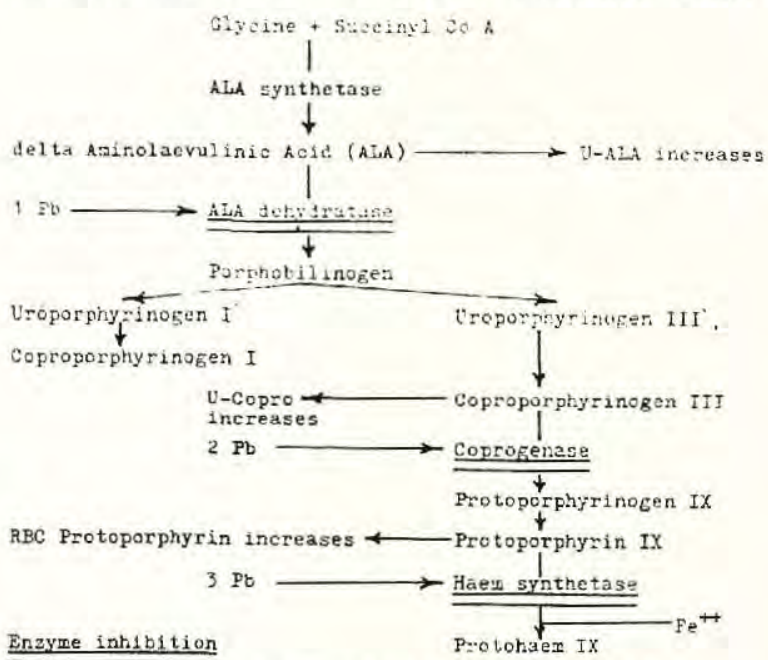

Site 1 Measure RBC ALAD. Measure U-ALA

Site 2 Measure $\mathrm{L}$-Coproporphyrin (unspecific test)

Site 3 Measure Free erythrocyte protoporphyrin (FEP) (intensive test in the low lead range)

Fig. 5 Diagram showing sites of action of $\mathbf{P b}$ and the secondary metabolic effects which are utilized in measuring toxic biological effect. 
Table I

Derived from Questionnaire

\begin{tabular}{|c|c|c|c|c|}
\hline$n$ & $\mathrm{x}$ age & $\begin{array}{l}x \text { length } \\
\text { of } \\
\text { service }\end{array}$ & Cigarettes per day & Alcohol gms per week \\
\hline
\end{tabular}

\begin{tabular}{|c|c|c|c|c|c|c|c|c|c|c|}
\hline & & & & 0 & $1-10$ & $11-20$ & $20+$ & NIL & $\begin{array}{l}10 \text { gms- } \\
280 \text { gms } \\
\end{array}$ & $\begin{array}{l}290 \text { gms- } \\
701) \text { gms } \\
\end{array}$ \\
\hline $\begin{array}{l}\text { Exposed } \\
\text { Non-exposed }\end{array}$ & $\begin{array}{r}35 \\
3\end{array}$ & $\begin{array}{l}21.9 \\
37\end{array}$ & $\begin{array}{r}4.2 \\
18.7\end{array}$ & $\begin{array}{r}15 \\
3\end{array}$ & 4 & 14 & 2 & $\begin{array}{l}4 \\
1\end{array}$ & $\begin{array}{r}23 \\
2\end{array}$ & 8 \\
\hline
\end{tabular}

than the porphobilinogen produced. Other techniques which measure the porphobilinogen tend to underestimate the activity of the enzyme as some of the porphobilinogen is converted onwards into porphyrins (Fig. 5).

The quantitative determination of urinary deltaaminolaevulinic acid (U-ALA) was estimated by the author using the Davis method ${ }^{9}$. The haemoglobin levels and WBC were obtained using an S5 Coulter counter and the lead content estimated using an AA-775 atomic absorption spectro photometer.

\section{Results}

\section{Questionnaire Data}

This is presented in Table I. The model and mean ages of the Group (Figure 6) reflect the age of active gun crews and are not the mean for the whole regiment which contains a proportion of

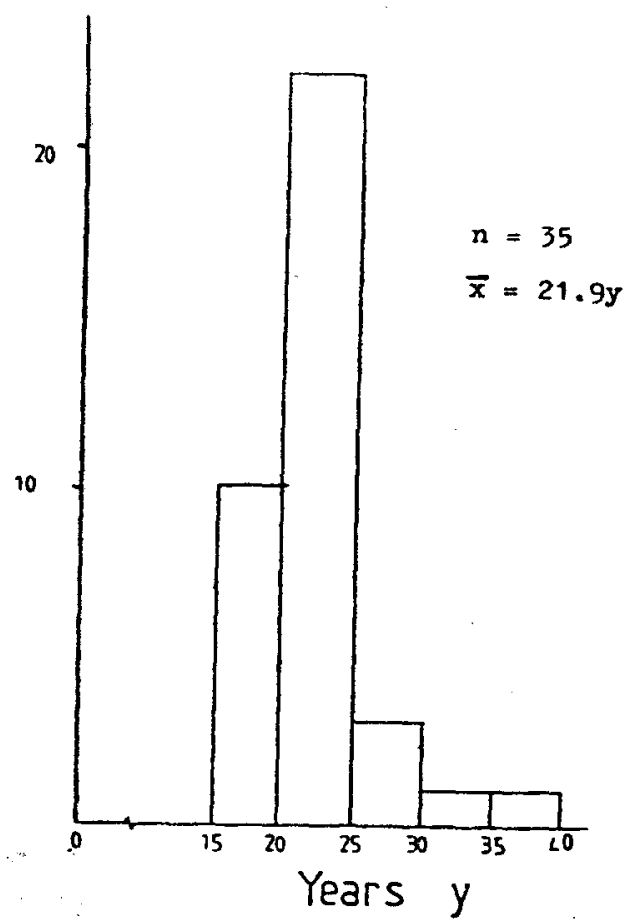

Fig. 6 Age of subjects
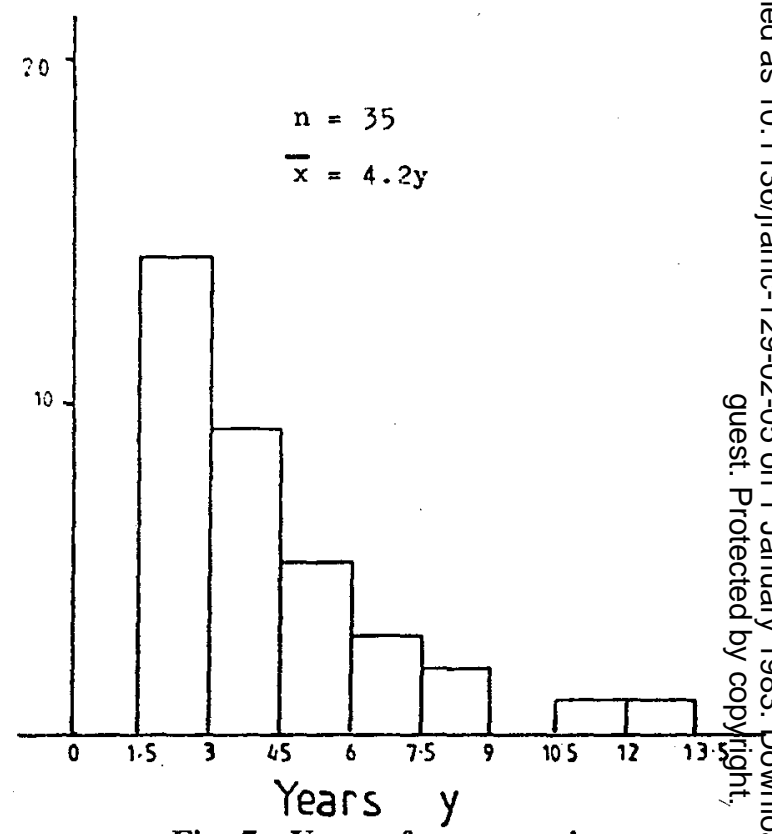

Fig. 7 Years of army service

older men, not directly involved with the guns. $\overrightarrow{\vec{P}}$ Length of service (Figure 7) mode reflects a similar 3 problem.

\section{Clinical}

As might be expected, this was a group of fairly fit young men with $34 / 38$ being within $10 \%$ of their optimum weight as assessed by actuarial tables $^{10}$. The other four (aged 20-22) were betweeno 20 and $25 \%$ overweight. Smokers constituted $60 \% \bar{F}$ of the exposed group (none of the medical staff smoked $0 / 3$ ) which is similar to a recent survey. carried out within the Army in Germany ${ }^{11}$. They compare unfavourably with the 1978 Household Survey figures which showed that $45 \%$ of all males 5 were smokers but closely reflect the SEG4 and 57 males from amongst whom most of the subjects have been recruited. There was one officer in the group No (non smoker).

Drinking was assessed in grammes of alcohol 0 consumed per week using $10 \mathrm{~g}$ measures as described ${ }^{\omega}$ 
by Paton in the $\mathrm{BMJ}^{12}$. These figures can only be taken as an indication of the alcohol intake of the group for there are confounding factors present in that, although the questionnaire was confidential, the volunteers may not have been confident that this was so. Indeed, it is - not unusual for the more immature to boast of high alcohol intake. Five claimed to be teetotal and the maximum intake was $640 \mathrm{~g}$ per week which is just below the $700 \mathrm{~g}$ per week considered to be damaging. However the higher quantities were invariably consumed in weekend binge drinking possibly leading to some acute morbidity

Although each subject was questioned as per the questionnaire, symptoms were very few. One patient complained of coryza which was clinically obvious and subject nine complained of cold hands in very cold weather. Subject nine was a non smoker and teetotal in his habits. Clinical examination showed no evidence of peripheral weakness or ischaemia and his history was not that of mild Raynaud's phenomenon. The four overweight individuals showed adequate muscular development to overcome their handicap at present.

\section{Environmental Data}

Air samples were taken over short periods only (Table II). This was necessary due to the severe weather and geographical conditions encountered during the survey with air temperatures of $-10^{\circ} \mathrm{C}$, snow and wind. A gunner's work is inherently dirty and the filter papers rapidly become begrimed with carbon, dirt and grease. There are two main groups of samples, those where the charge was "lead free" (no added lead foil) and the final 10 samples where charges four and six were used. Where more than

Table II

Lead content of charge -1 nil. 2 nil. $45 \mathrm{gm} .617 \mathrm{gm}$

\begin{tabular}{ccccc}
\hline Lab No & $\mathrm{mg} / \mathrm{m}^{3} \mathrm{~Pb}$ & $\begin{array}{c}\text { Time } \\
(\mathrm{M})\end{array}$ & TWA $(8 \mathrm{~h})$ & $\begin{array}{c}\text { Charge } \\
\text { Used }\end{array}$ \\
\hline $\mathrm{DEC} / 1$ & 0.0029 & 90 & 0.0015 & 1 or 2 \\
$\mathrm{DEC} / 2$ & 0.0036 & 90 & 0.0018 & 1 or 2 \\
$\mathrm{DEC} / 3$ & 0.0019 & 70 & 0.0012 & 1 or 2 \\
$\mathrm{DEC} / 4$ & Undetectable & 70 & 000 & 1 or 2 \\
$5 / 1$ & 0.0003 & 75 & 0.0002 & 1 or 2 \\
$5 / 2$ & 0.0026 & 75 & 0.0014 & 1 or 2 \\
$5 / 3$ & 0.0003 & 75 & 0.0002 & 1 or 2 \\
$5 / 4$ & 0.00003 & 75 & 0.07 & 1 or 2 \\
$26 / 1 \mathrm{~A}$ & 0.108 & 70 & 0.07 & 6 \\
$26 / 1 \mathrm{~B}$ & 0.112 & 70 & 0.07 & 6 \\
$\mathrm{~A} 17 / 21$ & 0.11 & 75 & & 4 \\
$\mathrm{~B} 17 / 22$ & 0.26 & 75 & & 4 \\
$\mathrm{~A} 17 / 23$ & 0.257 & 75 & $\mathrm{~A} .19$ & 6 \\
$\mathrm{~B} 17 / 24$ & 0.31 & 75 & & 6 \\
$\mathrm{~A} 17 / 25$ & 0.34 & 75 & & 6 \\
$\mathrm{~B} 17 / 26$ & 0.163 & 75 & $\mathrm{~B} 0.21$ & 6 \\
$\mathrm{~A} 17 / 27$ & 0.329 & 60 & & \\
$\mathrm{~B} 17 / 28$ & 0.317 & 60 & & 6 \\
\hline
\end{tabular}

two readings are given they are taken from the same two men throughout the day. Thus the final eight readings charted show four results over a total filtering time of 4 hours 45 minutes from two air samples.

Time weighted averages were estimated using an actual firing time of six hours per day. The length of the firing day is dictated by the training tasks in hand and also the amount of ammunition available. It is desirable to use the day's allocation as repacking is arduous and time consuming. This ensures that firing is maintained at a fairly steady rate throughout the day with one staggered break of about 30 minutes for a midday meal. The environmental lead will vary with the rate of fire. This rate is most variable when low charges are used. High charge is used only two or three times per month for specific training purposes and so the number of rounds fired tends to be more constant. 30 to 40 rounds per gun were used on the days of the survey.

The eight hour workday consists of about six hours exposure during firing and the rest con- $\frac{C}{0}$ sisting of a meal break and time spent in repairos and maintenance. Although there is only a total $?$ of 4 hours 45 minutes of sample time in the finalo $c$ series, to this must be added the time spent in changing filters and awaiting an opportune moment $\stackrel{\mathrm{D}}{\mathrm{D}}$ to reattach the filter heads, during which time firing continues. Thus the lead in air level for 4 hours $45<\overrightarrow{0}$ minutes is used to estimate the amount for sixO hours; hence an eight hour TWA for series A/17/2 (Table II).

$$
\begin{aligned}
& =\frac{[1.25(0.11+0.257+0.34)+0.329] \times 6}{8 \times 4.75} \\
& =0.19 \mathrm{mg} / \mathrm{m}^{3}
\end{aligned}
$$

\section{Haematological and biochemical data}

Blood Lead. The lowest observed value was 9.6 $\mu \mathrm{g} / \mathrm{dl}$ and the highest $30.1 \mu \mathrm{g} / \mathrm{dl}$. Mean for the group (n 35) was 19.25 (SD 4.9) Mean for the recruit sample (Figure 1) was $14.5 \mu \mathrm{g} / \mathrm{dl}$ (SD 6.3). Student's $t$ distribution test for the difference of means showed $t(d f 325)$ was 4.28 which gives a $P$ value of $<0.001$, highly significant. The difference is unlikely to be of clinical importance but reflects characteristics of the group to be discussed below.

Urinary Aminolaevulinic Acid; Levels were all within the normal range $(0-0.54 \mathrm{mg} \%)$ for this method. Maximum was $0.51 \mathrm{mg} \%$ (SD 17.9) RBC ALAD levels ranged from 22.5 to $43.63 \mu$ moles of ACA consumed per minute per litre of erythrocytes (n38, $\pm 31.71, S 5.79)$. These results fall closely into the normal range for the method $(22.4-44.5$, $\pm 33.8, S 4.8$ ). Thus both singly and as a group 
all the samples can be considered normal. For this group no correlation between whole blood lead and RBC ALAD was found. The WBC was normal in each case. The $\mathrm{Hb} \mathrm{g} / \mathrm{dl}$ values were also normal (min. 13.3, $\max 16.6$ ).

\section{Discussion}

Clinical effects of lead poisoning have been recognised from the time of Hippocrates, but recognition of subclinical effects date from more recent years. In 1965 Lloyd Davies discussed the problem in the Annual Report to HM Chief Inspector of Factories. Catton, Harrison, Fullerton and Kazantzis presented definitive evidence of subclinical neuropathy in $1970^{13}$ though in some cases there was other haematological evidence of toxicity. Further studies, one notably by Ashby ${ }^{14}$, have been carried out which show that subclinical neurological effects occur at levels oelow $80 \mu \mathrm{g} / \mathrm{dl}$. The inhibitory effect of low levels of lead on the biosynthesis of haem, through its inhibition of enzymes, has also been widely investigated, particularly with a view to their alteration with varying $\mathbf{B P b}$ levels ${ }^{15},{ }^{16}$. It is this inhibitory effect which has proved useful in the monitoring and investigation of low level occupational exposure to lead (Fig. V).

Enzymes and tests of their function vary in sensitivity and suitability for widescale use. End failure of haem synthesis leading to a reduction in haemoglobin levels is an insensitive criterion. There is a very wide range of levels at which this occurs and in many cases will be accompanied by other overt clinical signs. Blood lead is a precise measurement, but only in a general sense is it a good indication of a toxic lead environment. It is dependent on widely differing individual rates of absorption, deposition and excretion ${ }^{17}$. However, for large scale biological screening it is useful (following a positive environmental screen) and levels found in excess of those in the Control of Lead Regulations can lead to further more specific investigation. Although a capillary sample will suffice, it is permitted to carry out urine tests in lieu in Category B $(40-59 \mu / \mathrm{dl})$ groups at six month intervals, so long as an annual $\mathrm{BPb}$ is obtained. The most commonly used test is the urinary - ALA excretion.

RBC - ALAD inhibition was chosen for the survey in view of the expected low range of blood lead. Yamada et $\mathrm{al}^{16}$ demonstrated a good negative correlation between $\mathrm{BPb}$ and $\mathrm{RBC}$ - ALAD. Weissberg et al ${ }^{1.8}$ confirmed this and found a negative correlation between $\mathrm{BPb}$ and $\log$ ALAD $(r=-0.74)$ up to a level of $80 \mu \mathrm{g} / \mathrm{dl}$, above which there was no further decrease in ALAD activity. In his criteria he takes a group with a $\mathrm{BPb}$ less than $30 \mu \mathrm{g} / \mathrm{dl}$ as showing ALAD in the normal range. In the survey group correlation for ALAD and $\mathrm{BPb}$ was weak $(\mathrm{r}-0.2)$ but in view of Weissberg's finding it is possible a stronger corre- $\stackrel{\varnothing}{\varrho}$ lation might have appeared if a higher range of $O$ $\mathrm{BPb}$ had been found. The maximum level in the survey was $30.1 \mu \mathrm{g} / \mathrm{dl}$. Weissberg also carried out $\mathrm{U}$ - ALA estimations but did not consider them $\overrightarrow{\bar{N}}$ useful as the result was not uniformly positive? for levels above $80 \mu \mathrm{g} / \mathrm{dl}$. The survey $U$ - ALA 등 results were uniformly negative, reflecting the low levels of $\mathbf{B P b}$.

The survey was carried out to fulfil the require- $\frac{\mathbb{}}{\square}$ ments of the Regulations and so establish the extent of the problem with respect to an exposed $\overrightarrow{0}$ group of gunners. As noted earlier, a training unit $\overrightarrow{ }$ was selected as only members of one are likely to be at risk. Only they are involved with artillery firing on a daily, rather than a weekly, or rarer basis. It was important to assess the nature of the problem both at source, in the environment and $\vec{N}$ in its biological effects, on the subjects involved. Then, if required, further control could be initiated. N

Lead, as a hazard to the operator, had not pre- 0 viously been considered during development of the은 propellants. Preliminary investigation of the cop_stituents and adjuncts of propellants indicated thett there could be a significant discharge of metallig lead into the environment in the vicinity of te guns.

As information about these constituents is ngto readily available, two sets of air samples had alrea通. been obtained before the lead figures were aval able ${ }^{19}$. As can be seen in Table II the constituen of the differing charges relate well to the lead levelo in air obtained. The TWA for eight hours for: series $A / 17 / 2$ was $0.19 \mathrm{mg} / \mathrm{m}^{3}$ which, if main- $\stackrel{\Phi}{\varrho}$ tained, would be above the Lead in Air Standard $\vec{O}$ $\left(0.15 \mathrm{mg} / \mathrm{m}^{3}\right)$. Conversely, the eight hour TWA when low charge propellants are used is insignificantly low. Scrutiny of the firing programme sug-ơ gests a maximum usage of high charge ammunition on three days per month. Time weighting for a 40 hour week, allowing for normal use of all types of charge, will thus reduce the TWA for series $A / 17 / 2$ to $0.03 \mathrm{mg} / \mathrm{m}^{3}$ which is well below@ the standard for which routine monitoring is man-? datory. It is unlikely that training with high charge propellant is ever likely to be increased sufficiently. to produce significant levels. However, it was notedO that the amount of lead foil used in $155 \mathrm{~mm}$ high charge propellant was $200 \mathrm{~g}$ and some further in-을 vestigation of operating practice and environmental sampling with this larger gun may be warranted.

This survey group of soldiers is not part of aN cohort of a Manser's recruit group. However, both groups have been recruited from a similar popula-N tion sample so some comparison is reasonable. 
The mean age of the recruit group is unknown though it will be of the order of four years less than the survey group ( $x$ length of service from time of recruitment was 4.2 years). Only a proportion of the recruits will have joined the Artillery but this will have been a random sample with respect to their initial blood lead levels. The range of blood lead found in both surveys was normal and acceptable as defined by the reference levels of the EEC Directive ${ }^{20}$. In Manser's group (n292) $85 \%$ had blood levels below $20 \mu \mathrm{g} / \mathrm{dl}$ and $96 \%$ below $30 \mu \mathrm{g} / \mathrm{dl}$. In this survey $48 \%$ had levels below $20 \mu \mathrm{g} / \mathrm{dl}$ and $96 \%$ below $30 \mu \mathrm{g} / \mathrm{dl}$. These normal levels are reflected in the normal RBC - ALAD and $U$ - ALA results obtained. The difference in means of $\mathrm{BPb}$ between the recruit and survey groups of $4.7 \mu \mathrm{g} / \mathrm{dl}$ is statistically significant $(\mathrm{p}<0.001)$. Whether this rise is merely age related due to continued lead absorption from a low environment or is specifically due to an occupational source of lead cannot be clarified by this survey. A cohort study on Manser's group investigating the eventual military employment of the recruits vis a vis $\mathbf{B P b}$ would help. It may be that there is an initial rise within the first 18 months of service due to a slightly higher environmental lead level which then stablizies at a slightly higher, but nonetheless clinically unimportant level ${ }^{21}$. There was no evidence to show that $\mathrm{BPb}$ rose with length of service $(r=0.16)$.

In view of the negative findings of this survey it is considered that the Regulation requiring the provision of protective clothing, air monitoring techniques and biological testing will not apply (Approved Code of Practice, para 3). ${ }^{7}$.

\section{Acknowledgements}

I am indebted to Col A G Harwood of the Army Occupational Health Research Unit at Farnborough for his help and advice and to Major John Allen MBE RA (Retd) and all ranks of the Second Field Regiment Royal Artillery for their patience, hospitality and help.
REFERENCES

1 Defence Central Medical Service (PE) Papers 1946-1954.

2 LANDRIGAN P J et al. Chronic lead absorption. J A M A 1976; 234: 394.

3 SMITH D L. Lead absorption in Police Small-arms Instructors. J Soc Occup Med 1976: 26: 139-140.

4 MUSKeTt $C$ J and CASWELl $R$. An investigation into lead in two indoor small-bore rifle ranges. Ann Occup Hyg 1980; 23: 283-294.

5 Harwood A G, Manser D W and Pashen T. Airborne lead contamination in Army Indoor ranges. APRE paper (unpublished) 1981.

6 Health and Safety at Work Act 1974; para 48.

7 HMSO Control of Lead at Work Regulations 1980; No. 1248.

8 TomokUNI K. New method for determination of Aminolaevulinate dehydratase activity of Human erythrocytes as an Index of Lead Exposure. Clin Chem 1974; 20: 1287-1291.

9 Davis J R, Andolman S L. A method for measuring delta - ALA in urine. Arch Environ Health 1967; 15: 53-59.

10 Society of Actuaries Build and Blood Pressure Study (Vol. 1) Chicago 1959.

11 I (BR) Corps Health Survey 1980

12 Paton A. SAunders J B. ABC of Alcohol. $\mathrm{Br}$ Med J 1981; 283: p1381.

13 Catton M J, Harrison M J G, Fullerton P M KazanTzIS G. Subclinical Neuropathy in Leads Workers. $\mathrm{Br}$ Med J 1970; 2: 80-82.

14 AshrY J A S. A neurological and biochemical study 0 of early lead poisoning. $B r \quad J$ Industr Med 1980 37: $133-140$

15 Allessio L, Castoldi $M \quad R$, Odone $P$ ando FRANCHINI I. Behaviour of indicators of exposure and effect after cessation of occupational exposure to lead. Br $J$ Industr Med 1981; 38: 262-267.

16 Yamada Y, KIDO T, OKADA A, et al. Estimation of usefulness of some biochemical tests as paras meters for occupational lead exposure. Jap Industr Health 1981; 23: 260-269.

17 WALDRON H A, STOFEN D. Subclinical Lead poisoning. 1974. Academic Press.

18 WeIsSberg J B, Lipschutz F, OSKI F A. Deltaaminolaevulinic Acid dehydratase activity in circulating blood cells. New Engl J Med 1971; 284: 565-569.

19 Personal communication from the Royal Armament Research and Development Establishment.

20 EEC Directive 77/312/EEC 28 April 1977.

21 LEE W R. What happens in Lead Poisoning? $J R$ Coll Phys Lond. 1981; 15: 48-54. 